Reprod. Nutr. Dévelop., 1983, 23 (1), 93-100.

\title{
Diurnal rhythms in the synthesis and release of haemolymph proteins in the crustacean Isopoda, Porcellio dilatatus (Brandt), with special reference to vitellogenin
}

\author{
M. GOHAR, Catherine SOUTY, J. L. PICAUD \\ Université de Poitiers, Laboratoire de Biologie animale, \\ "Physiologie et Génétique des Crustacés", E.R.A. CNRS No 230, \\ 40, avenue du Recteur Pineau, 86022 Poitiers Cedex, France.
}

Summary. Synthesis and release of vitellogenin in the crustacean Isopoda, Porcellio dilatatus, were maximal during premolt. At that time, diurnal variations occurred in the haemolymph protein level and in the synthesis and release of vitellogenin and other proteins in the haemolymph. The pattern of variations was always identical and bimodal : the minima were at dusk and at dawn when the maxima occurred in the middle of the day and of the night. These variations were highly significant, and the diurnal means were significantly higher than the nocturnal means.

\section{Introduction.}

Oocyte yolk inclusions in insects are composed of an endogenous fraction and an exogenous fraction (see review by Engelmann, 1970). In several crustacean isopods, this inclusion takes place particularly in stage 2 of vitellogenesis; in Porcellio dilatatus oocyte volume increases considerably $(250 \mu \mathrm{m}$ to $700 \mu \mathrm{m}$ according to Besse, 1976) during this stage.

In /dotea balthica the incorporation processes, demonstrated at ultrastructural level by numerous images of pinocytosis in the oolemma of vitellogenic oocytes, are concomitant with enlargement of the spaces between follicular cells (Souty, 1980). This process permits the vitellogenin, formerly called " female-specific protein " in $P$. dilatatus and Ligia oceanica (Besse and Mocquard, 1968), to penetrate inside the oocytes. Vitellogenin, the precursor of intraoocyte yolk protein (Junéra and Meusy, 1982), is antigenically indistinguishable from it (Kerr, 1969; Croisille et al., 1974 ; Picaud, 1978). It represents the major part of the exogenous yolk fraction and its incorporation is specific, at least in insects (Telfer, 1960; Kunkel and Pan, 1976; Ferenz, 1978; Ferenz et al., 1981). The fat body constitutes the extraovarian source of vitellogenin in $P$. dilatatus (Picaud and Souty, 1980), I. Balthica (Souty and Picaud, 1981) and Orchestia gammarellus (Junéra and Croisille, 1980). According to Picaud and Souty (1981), the synthesis 
and release of vitellogenin by the fat body of $P$. dilatatus undergoes changes during the molt cycle, being maximal in premolt, i.e. in the $D_{1}^{\prime \prime}, D_{1}^{\prime \prime \prime}$ and $D_{2} a$ stages of Drach and Tchernigovtzeff (1967) adapted to $P$. dilatatus by Noulin (personal communication).

At these stages of the molt cycle we investigated putative diurnal changes in haemolymph protein levels and in synthesized and released vitellogenin and total protein over a given period.

\section{Material and methods.}

We used virgin females having the same origin and weighing between 90 and $130 \mathrm{mg}$; they were the issue of a group reared under natural photoperiod at $20^{\circ} \mathrm{C}$. At the end of January the females were isolated and submitted to a photoperiod of $14 \mathrm{~L}: 10 \mathrm{D}$. After they had been with males for one week, $95 \%$ of them began to reproduce. In our experimental conditions, they were able to carry out several successive vitellogeneses. According to Mocquard et al. (1976), these females were in molt stages $D_{1}^{\prime \prime}$ to $D_{2}$ a 9 to 13 days after pullus was released.

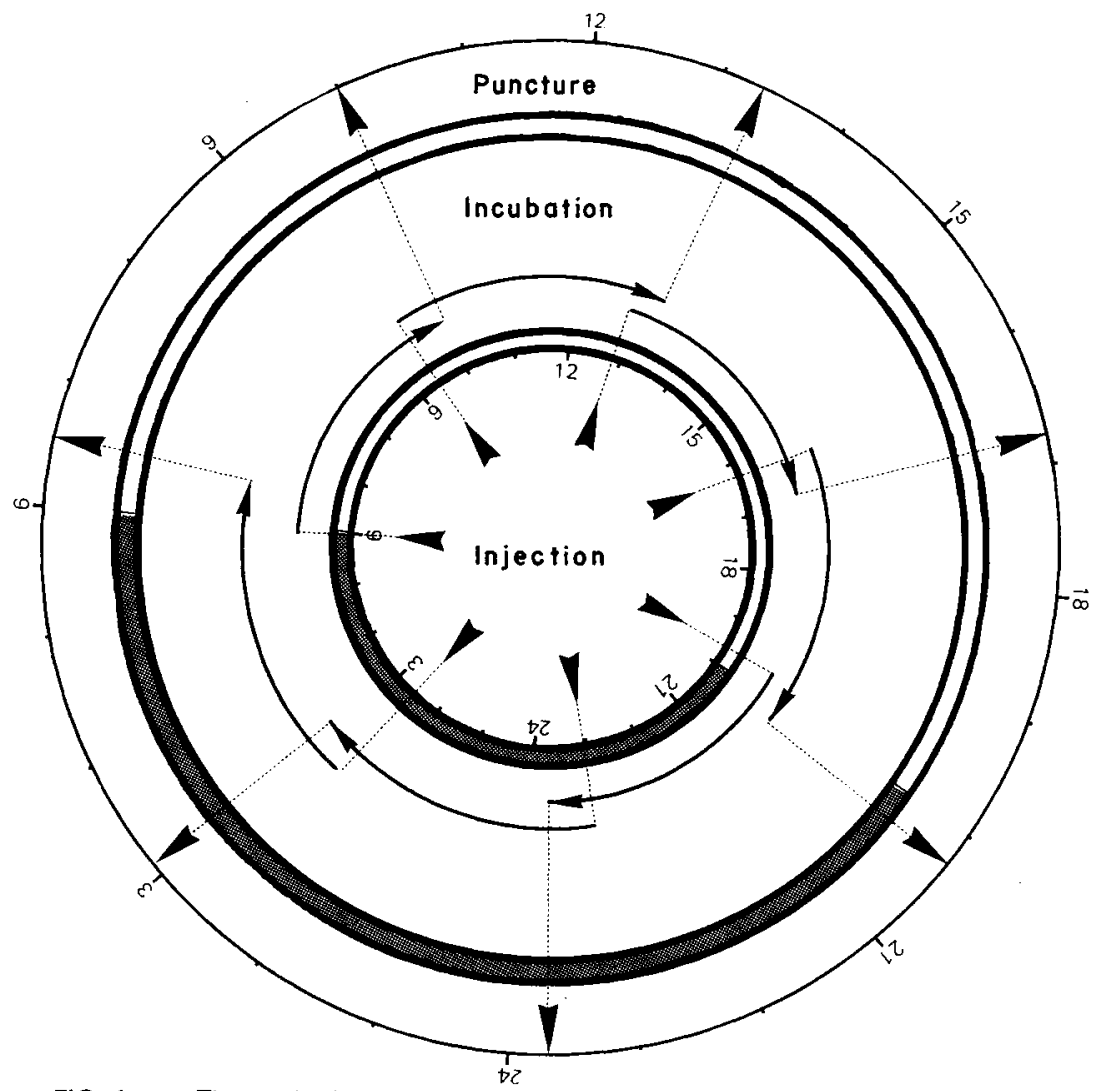

FIG. 1. - Time schedule used in radioactive labelling of haemolymph protein. Numbers : times of day. Black and white circles : photoperiod (14L : 10D). 
At these presumed stages, several groups of females were tested at 7 points during the 24-hour period (fig. 1). To radioactively label the haemolymph proteins, each female was given an injection of $0.2 \mu \mathrm{Ci}$ of ${ }^{14} \mathrm{C}$-leucine (Amersham France ; specific activity $=350 \mathrm{mCi} / \mathrm{mmole}$ ) contained in a volume of $4 \mu \mathrm{l}$. Four hours after injection, $9 \mu$ of haemolymph were withdrawn from each female by puncture (fig. 1) and diluted in $600 \mu \mathrm{l}$ of physiological solution.

For treatment, we used the protocol described by Souty and Picaud (1981), Picaud and Souty (1981) and summarized on figure 2. The antivitellogenin antiserum was prepared in rabbit by injecting an extract of ovaries in early stage 2 of vitellogenesis in which the vitellogenin and the vitellin composed the major part of the ovarian proteins (Picaud and Besse, 1973). This extract was rendered monospecific against those proteins by absorption with male haemolymph.

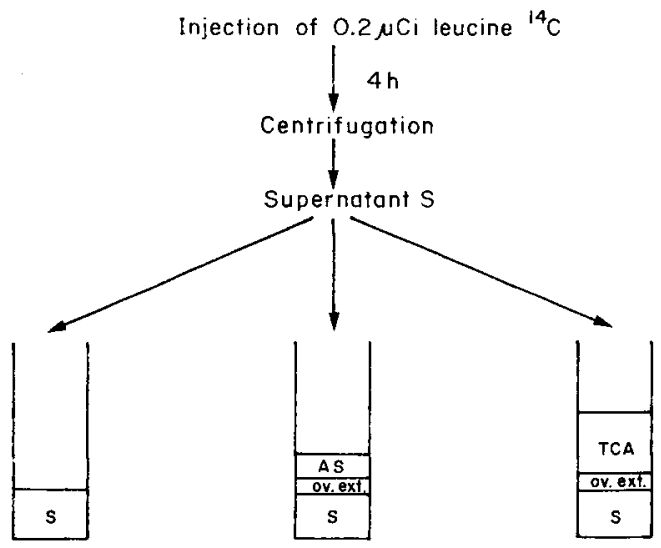

Total proteins

(Method of Hortree(1972) with BSA os a standard)
Immunoprecipitote

Labelled vitellogenin (synthesized)

$$
\begin{aligned}
& \text { "Antigen-Antibody complex" } \\
& \text { precipitates washed } \\
& \text { with physiological } \\
& \text { serum three times } \\
& \text { like total proteins } \\
& \text { Final precipitates dissolved in } 50 \mu \text { IN NaOH } \\
& + \text { Scintillation mixture } \\
& \text { † } \\
& \text { Liquid scintillation counting (c.p.m.) }
\end{aligned}
$$

\section{FIG. 2. - Methods of protein analysis.}

$S=$ three samples of $100 \mu \mathrm{l}$ each ; $\mathrm{AS}=$ antiserum. The amount of AS was determined by titration curves and microtests. AS added, incubated for $1 \mathrm{~h}$ at $30^{\circ} \mathrm{C}$ and then overnight at $4{ }^{\circ} \mathrm{C}$. ov. ext. $=$ ovarian extract ; TCA $=$ trichloracetic acid.

Total unlabelled proteins were measured by the method of Hartree (1972) at the time of puncture and expressed in $\mu \mathrm{g}$ of equivalent albumin.

The labelled proteins and vitellogenin were expressed in CPM per $\mu$ l of haemolymph, thus giving the quantities synthesized during the $4 \mathrm{hrs}$ between injection and puncture. 
At the end of each manipulation, 2 pereiopods were sampled, fixed, dehydrated and mounted to exactly determine molt cycle stage.

\section{Results.}

1. Haemolymph protein level. - Figure 3 shows data obtained on the levels of haemolymph protein. The lowest value occurred at the beginning of the dark phase; the level then rapidly increased during the night and more slowly after daybreak, reaching a maximum at midday. This maximum was $75 \%$ higher than the minimum observed $7 \mathrm{~h}$ later. Protein level heterogeneity was significant at the $5 \%$ level. The diurnal and nocturnal mean levels showed a significant difference at the $1 \%$ level, the diurnal mean being $22 \%$ higher than the nocturnal mean.

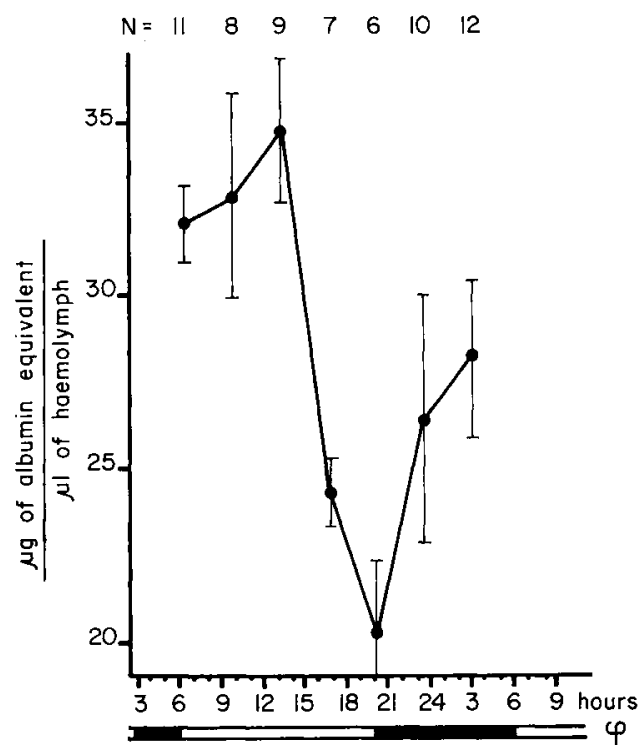

FIG. 3. - Haemolymph protein level.

$N=$ number of animals tested ; $\varphi=$ photoperiod $(14 \mathrm{~L}: 10 \mathrm{D})$.

2. Synthesis and release of total haemolymph protein. - As the haemolymph protein level, that of the labelled protein of the haemolymph showed a minimal value at the beginning of the scotophase. Then, these synthesized and released proteins increased continuously during the night (fig. 4).

They were low in the early morning but maximal in the late morning. This maximum was 7 times higher than the minimum and diurnal fluctuation was significant at the $1 \%$ level. The diurnal mean was $70 \%$ higher than the nocturnal mean, the difference being significant at the $1 \%$ oo level. 
3. Vitellogenin synthesis and release in the haemolymph. - The fluctuation of labelled haemolymph vitellogenin (fig. 5) during the 24-hour cycle was the same as that of the labelled haemolymph protein. The late morning maximum represented 13 times the minimum situated in the early night. The fluctuation of synthesized and released vitellogenin, significant at the $1 \%$ oo level, was thus considerable. Compared to the diurnal and nocturnal means, the difference was significant at the $5 \%$ o level with a diurnal mean $33 \%$ higher than the nocturnal mean.

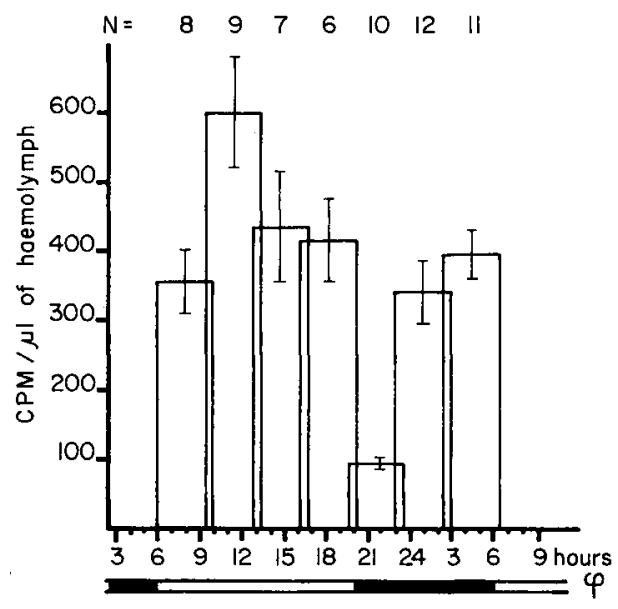

FIG. 4.

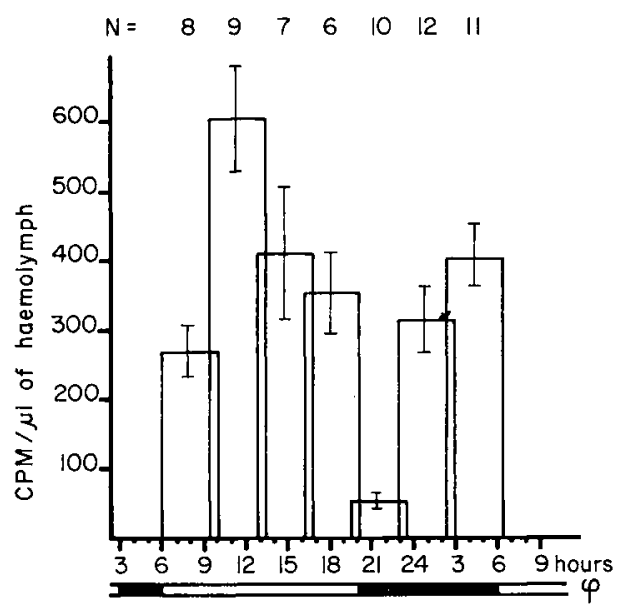

FIG. 5 .

FIG. 4. - Synthesis and release of total protein in the haemolymph. Same symbols and conventions as figure 3 .

FIG. 5. - Vitellogenin synthesis and release in haemolymph.

Same symbols and conventions as figure 3 .

Labelled vitellogenin, expressed in percentage of labelled total protein, also showed bimodal fluctuation during the day (significant at the $1 \%$ level) with a minimum of $57 \%$ situated in the early night. Its highest value (99\%) occurred in the late night and the day-night difference was not significant at the $5 \%$ level.

\section{Discussion.}

The data presented here demonstrate that the release of vitellogenin in $P$. dilatatus follows a diurnal rhythm in late vitellogenic females and in premolt. This large-amplitude rhythm, which must be considered in all studies on vitellogenin metabolism, nevertheless does not disagree with the results of Picaud and Souty (1981) cited previously since the studies were always carried out at the same hour. 
During the 24-hour cycle the haemolymph protein level changed in the same way as did the synthesis and release of vitellogenin. However, according to electropherograms of vitellogenic females of $P$. dilatatus (Picaud and Besse, 1973), vitellogenin may represent 5 to $20 \%$ of the total protein. The proportion of vitellogenin to total haemolymph protein in insects is situated within these limits ; $5 \%$ in Diploptera punctata (Mundall, Tobe and Stay, 1981) and $25 \%$ in Locusta migratoria (Ferenz, 1978).

Consequently, the amount of vitellogenin does not appear to be large enough to explain the fluctuations of total protein by vitellogenin release according to diurnal rhythm. However synthesized and released vitellogenin represents at least $57 \%$ and, on an average, $80 \%$ of synthesized protein released in the haemolymph between injection and puncture. Thus, it is probable that a large part of the total proteins released at the rhythm we found, is not labelled, i.e. they were synthesized more than $4 \mathrm{~h}$ before they were released.

Wieser, Schweizer and Hartenstein (1979) studied protein catabolism in two crustacean isopods, Porcellio scaber and Oniscus asellus. According to these authors who used the males of these species, ammoniac excretion, reflecting protein turnover, follows a diurnal rhythm homologous to the one we observed. This would confirm the hypothesis of a protein-releasing rhythm in $P$. dilatatus, as described previously.

On the other hand, diurnal changes in the enzymatic activities of Penaeus kerathurus (Van Wormhoudt, Ceccaldi and Le Gal, 1972) are bimodal and approximately the reverse of the rhythms we found. The same phenomenon occurs for some enzymes of the abdominal muscle of Palaemon squilla (Trellu and Ceccaldi, 1977).

Finally, Chentoufi (1982) recently studying Armadillidium vulgare (Crustacea, Isopoda) showed a circadian rhythm for breathing that was similarly bimodal and in reverse phase with the rhythms of protein release in $P$. dilatatus.

\section{Conclusion.}

Most of the physiological rhythms observed in this study present either maxima or minima at the borderline between day and night and inversely, indicating dependence on photoperiodic rhythms.

On the other hand, as the photoperiod is the principal external factor controlling reproduction in isopods $(P$. dilatatus: Mocquard et al., 1978 ; Armadillidium vulgare : Mocquard et al., 1980), it is possible that diurnal rhythms have direct control over reproduction.

The existence of such a rhythm offers a new field of investigation concerning vitellogenin. Moreover, vitellogenin, which is the object of much study, seems to be suitable for investigating diurnal rhythm control.

Reçu en juillet 1982.

Accepté en août 1982.

Acknowledgements. - We wish to thank L. Nasreddine for typing the paper. 
Résumé. Rythme nycthéméral de synthèse et de libération de la vitellogénine et des protéines hémolymphatiques chez le crustacé lsopode terrestre, Porcellio dilatatus (Brandt).

Dans l'hémolymphe de l'isopode terrestre Porcellio dilatatus, le niveau maximum de synthèse et de libération de vitellogénine est atteint en prémue. A cette période du cycle de mue, on observe des variations nycthémérales du taux des protéines hémolymphatiques, de la synthèse et de la libération de vitellogénine et des autres protéines dans l'hémolymphe. Dans tous les cas, le schéma de variation est identique et bimodal : au crépuscule et à l'aube se situent les minimums, au milieu du jour et de la nuit les maximums. Les variations observées sont hautement significatives et les moyennes diurnes sont significativement supérieures aux moyennes nocturnes.

\section{References}

BESSE G., 1976. Contribution à l'étude expérimentale de la physiologie sexuelle femelle chez les Crustacés /sopodes terrestres. Th. Doct. Etat, Univ. Poitiers, CNRS, France $n^{\circ} 10,13017$.

BESSE G., MOCQUARD J. P., 1968. Etude par électrophorèse des quantités relatives des protéines de l'hémolymphe d'individus normaux et de femelles castrées chez deux Crustacés Oniscoïdes : Porcellio dilatatus Brandt et Ligia oceanica L. C.R. Acad. Sci. Paris, Sér. D, 267, 2017-2019.

CHENTOUFI A., 1982. Contribution à l'étude de l'écophysiologie d'Armadillidium vulgare /Crustacé, /sopode terrestre). Th. $3^{\text {e }}$ cycle, Univ. Poitiers.

CROISILLE Y., JUNERA H., MEUSY J.-J., CHARNIAUX-COTTON H., 1974. The female-specific protein (vitellogenic protein) in Crustacea with particular reference to Orchestia gammarellus (Amphipoda). Amer. Zool., 14, 1219-1228.

DRACH P., TCHERNIGOVTZEFF C., 1967. Sur la méthode de détermination des stades d'intermue et son application générale aux Crustacés. Vie et Milieu Biol. mar., 18, 595-610.

ENGELMANN F., 1970. The physiology of insect reproduction. Pergamon Press.

FERENZ. H. J., 1978. Uptake of vitellogenin into developing oöcytes of Locusta migratoria. . Insect Physiol., 24, 273-278.

FERENZ H. J., LUBZENS E., GLASS H., 1981. Vitellin and viteilogenin incorporation by isolated oöcytes of Locusta migratoria migratoroïdes (R.F.). J. Insect Physiol., 27, 869-875.

HARTREE E. F., 1972. Determination of protein : a modification of the lowry method that gives a linear photometric response. Anal. Biochem., 48, 422-427.

JUNÉRA H., CROISILLE Y., 1980. Recherche du lieu de synthèse de la vitellogénine chez le Crustacé Amphipode Orchestia gammarella (Pallas). Mise en évidence d'une activation de la synthèse protéique dans le tissu adipeux sous-épidermique en liaison avec la production de vitellogénine. C.R. Acad. Sci. Paris, Sér. D, 290, 703-706.

JUNÉRA H., MEUSY J. J., 1982. Vitellogenin and lipovitellins in Orchestia gammarellus (Pallas) (Crustacea, Amphipoda), labelling of subunits after in vivo administration of ${ }^{3} \mathrm{H}$-leucine. Experientia, 38, 252-253.

KERR M. S., 1969. The hemolymph proteins of the blue crab, Callinectes sapidus. II. A lipoprotein serologically identical to oöcyte lipovitellin. Develop. Biol., 20, 1-17.

KUNKEL J. G., PAN M. L., 1976. Selectivity of yolk protein uptake. Comparison of vitellogenins of two insects. J. Insect Physiol., 22, 809-818.

MOCQUARD J. P., BESSE G., JUCHAULT P., LEGRAND J. J., MAISSIAT J., MARTIN G., PICAUD J. L., 1976. Durée des cycles de mue chez les femelles de l'Oniscoïde Porcellio dilatatus Brandt, suivant leur état sexuel et les conditions d'élevage : température, photopériode et groupement. Bull. Ecol., 7, 297-314.

MOCQUARD J. P., BESSE G., JUCHAULT P., LEGRAND J. J., MAISSIAT J., MARTIN G., PICAUD J. L., 1978. Action de la température et de la photopériode sur l'induction des mues parturielles des femelles de Porcellio dilatatus Brandt (Crustacé Isopode Oniscoïde). Arch. Zool. exp. Gén., 119, 409-432. 
MOCQUARD J. P., PAVESE A., JUCHAULT P., 1980. Déterminisme de la reproduction saisonnière des femelles d'Armadillidium vulgare Latr. (Crustacé, Isopode, Oniscoide). I. Action de la température et de la photopériode. Ann. Sci. nat. Zool. Paris, 2, 91-97.

MUNDALL E. C., TOBE S. S., STAY B., 1981. Vitellogenin fluctuations in haemolymph and fat body and dynamics of uptake into oöcytes during the reproductive cycle of Diploptera punctata. J. Insect Physiol., 27, 821-827.

PICAUD J. L., 1978. Parentés antigéniques des protéines spécifiques femelles chez quelques Crustacés Isopodes. C.R. Soc. Biol., 172, 320-324.

PICAUD J. L., BESSE G., 1973. Les protéines de I'hémolymphe et de l'ovaire de Porcellio dilatatus $\mathrm{Br}$. : leurs variations en fonction de la vitellogenèse. C.R. Acad. Sci. Paris, Sér. D, 276, 2207-2210.

PICAUD J. L., SOUTY C., 1980. Démonstration par immunoautoradiographie de la synthèse de la vitellogénine par le tissu adipeux de Porcellio dilatatus Brandt (Crustacé, Isopode). C.R. Acad. Sci. Paris, Sér. D, 290, 1019-1021.

PICAUD J. L., SOUTY C., 1981. Approche quantitative de l'influence de l'ovariectomie sur la synthèse de la vitellogénine chez Porcellio dilatatus Brandt (Crustacé, Isopode). C.R. Acad. Sci. Paris, Sér. D, 293, 479-482.

SOUTY C., 1980. Electron microscopy study of follicle cell development during vitellogenesis in the marine crustacean Isopoda, Idotea balthica basteri. Reprod. Nutr. Dévelop., 20, 653-663.

SOUTY C., PICAUD J. L., 1981. Vitellogenin synthesis in the fat body of the marine crustacean Isopoda, Idotea balthica basteri, during vitellogenesis. Reprod. Nutr. Dévelop., 21, 95-101.

TELFER W. H., 1960. The selective accumulation of blood proteins by the oöcytes of saturniid moths. Biol. Bull. mar. biol. Lab., Wood' Hole, 118, 338-351.

TRELLU J., CECCALDI H. J., 1977. Circadian variations of some enzymatic activities in Palaemon squilla Linné (1758) (Crustacea, Decapoda). J. interdiscipl. Cycle Res., 8, 357359.

VAN WORMHOUDT A., CECCALDI H. J., LE GAL Y., 1972. Activité des protéases et amylases chez Penaeus kerathurus: existence d'un rythme circadien. C.R. Acad. Sci. Paris, Sér. D, 274, 1208-1211.

WIESER W., SCHWEIZER G., HARTENSTEIN R., 1969. Patterns in the release of gaseous ammonia by terrestrial isopods. Oecologia, 3, 390-400. 